\title{
Interactions of Developing Neurons with the Extracellular Matrix
}

\author{
Paul C. Letourneau, Maureen L. Condic, and Diane M. Snow \\ Department of Cell Biology and Neuroanatomy, University of Minnesota, Minneapolis, Minnesota 55455
}

The differentiation and morphogenesis of neural tissues involves a diversity of interactions between neural cells and their environment. Many potentially important interactions occur with the extracellular matrix (ECM), a complex association of extracellular glycoproteins organized into aggregates and polymers. In this article, we discuss recent findings on neuronal interactions with the ECM and their roles in neural cell migration and neurite growth. First, we examine the expression and putative functions of the molecules of the neural ECM. Second, we discuss cell surface molecules that mediate neural interactions with ECM components. Last, we address proteoglycans (PGs), a diverse class of glycoproteins, present both as ECM components and as cell surface molecules, which may mediate neural interactions with their environment.

The best-understood cellular interactions with the ECM are adhesive, mediated by binding between specific cell surface molecules and cell binding domains of ECM components (Strittmater and Fishman, 1991; Damsky and Werb, 1992). Cellsubstratum adhesion is necessary for major cell movements of neuron morphogenesis, that is, the migrations of neural cells and their precursors and the migratory behavior of growth cones at the extending tips of axons and dendrites. As cells move, adhesive molecules at the surface of the leading edge of a migrating cell or growth cone bind to ligands on other cell surfaces or ECM components. These bonds stabilize filopodia and lamellipodia, and, in some cases, provide anchorage against which cytoskeletal filaments, associated with the plasma membrane, exert forces to pull the cell or growth cone forward. Thus, FCM has been primarily viewed as an adhesive substratum to provide traction for migrating cells and to stabilize the position and, perhaps, the state of differentiation of nonmotile cells.

However, the interactions between neural cells and the ECM are not longer regarded as only adhesive or mechanical. Two points are now clear. First, some of these interactions are definitely not adhesive, but, rather, they may even be antiadhesive (Chiquet-Ehrismann, 1991). Second, evidence has accumulated to indicate that the cell surface molecules that mediate cell-cell and cell-ECM interactions (immunoglobulin superfamily, cad-

\footnotetext{
Preparation of this review was supported by NIH Grants HD19950 and NS28807 (P.C.L.), NIH Grant EY06331-01 (D.M.S.), and a grant from the American Cancer Society (M.L.C.).

Correspondence should be addressed to Paul C. Letourneau, University of Minnesota at Minneapolis, Department of Cell Biology and Neuroanatomy, 321 Church Street S.E., 4-135 Jackson Hall, Minneapolis, MN 55455.

Copyright @ 1994 Society for Neuroscience 0270-6474/94/1409!5-14\$05.00/0
}

herins, integrins) modulate the same cytoplasmic second messenger pathways (e.g., cytoplasmic $\left[\mathrm{Ca}^{2+}\right]$, protein kinases, inositol phosphates), as do hormones, growth factors, neurotransmitters, and pharmaceuticals (reviewed in Damsky and Werb, 1992; Hynes, 1992; Hynes and Lander, 1992; Schweighoffer and Shaw, 1992; Thiery and Boyer, 1992). Thus, neural cell-ECM interactions are more complex than they were previously thought to be. These interactions may generate signals that directly regulate locomotory activities, such as polymerization of cytoskeletal components and associations of cytoskeleton and plasma membrane, that produce extension and adhesion of lamellipodia and filopodia and generate mechanical force. In addition, these signals may act in cell nuclei to alter gene expression of proteins involved in neuronal migration and morphogenesis.

\section{Extracellular Matrix Molecules}

Organization and diversity of the ECM in developing neural tissues

Embryonic neural tissues contain a dynamic ECM, composed of many types of molecules that have distinct patterns of spatial and temporal expression. Many ECM components, originally discovered in non-neural tissues, are also present in developing neural tissues, including fibronectin (FN), laminin (LM), vitronectin, collagens, PGs, tenascin, and thrombospondin (Reichardt and Tomaselli, 1991). Some ECM components were originally discovered in neural tissues, such as S-laminin and agrin, which are concentrated in the basement membrane at neuromuscular junctions (Reist et al., 1987; Hunter et al., 1989a,b), and F-spondin, which is abundantly expressed in the spinal cord floor plate (Klar et al., 1992).

Many ECM components are modular or mosaic proteins, composed of several polypeptide domains that can be differentially assembled as a consequence of alternative mRNA splicing (Engel, 1991). These domains build characteristic motifs of polypeptide folding, and they are often named for the protein in which they were first recognized, for example, FN type I, II, III; epidermal growth factor (EGF)-like; immunoglobulin-like; carboxy-terminal LM globule(Fig. 1). The structural similarities of any domain type in different proteins are greater than peptide sequence similarities, and a pressing question is whether structural similarity entails functional similarity for a domain, as it exists in different ECM and cell surface proteins. Alternative mRNA splicing permits multiple combinations of these structural domains, thereby increasing the potential for functional 


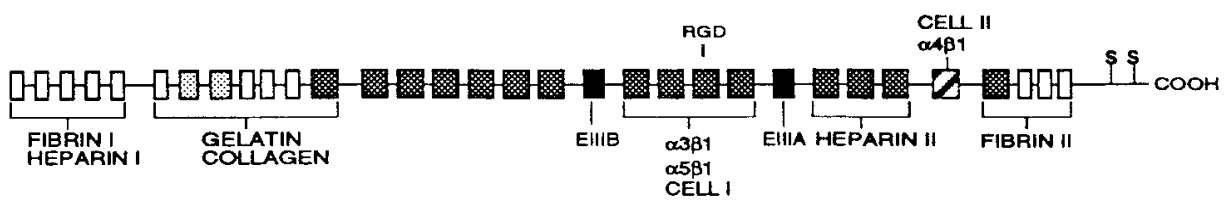

册口

(4)

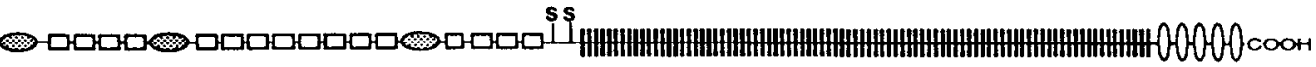

(86)
FIBRONECTIN

TENASCIN

LAMININ A CHAIN

COllagen IV $(\infty 3)$

THROMBOSPONDIN

\section{HWHD}

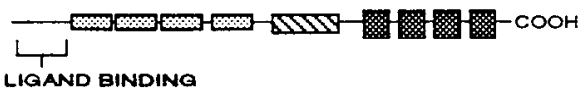

INTEGRIN $\beta 4$

LIOAND BINDINO

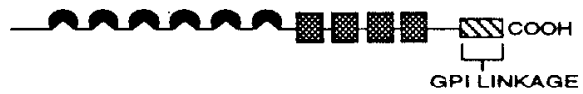

F11 RECEPTOA

\begin{tabular}{|c|c|c|c|c|c|c|c|}
\hline 1 & HEPTAD REPEAT & $D$ & FIBAINOGEN & 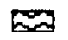 & GXY REPEAT & 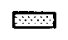 & CYSTEINE-AICH \\
\hline D & FIBRONECTIN TYPE I & $\square$ & EGF REPEAT & 0 & VON WLLEBRAND TYPE A & ค & IgG REPEAT \\
\hline 3 & FIBRONECTIN TYPE II & $\diamond$ & PROPEADIN & $\leftrightarrow$ & LAMININ GLOBULAP DOMAIN & $\mathbf{B}$ & TRANSMEMBPANE \\
\hline & FIBRONECTN TYPE III & $\$$ & CALCIUM BINDING & 0 & LAMININ GLOBULAR G1-G5 & $\boldsymbol{\gamma}$ & LOL PECEPTOA DOMANN \\
\hline
\end{tabular}

Figure 1. A schematic illustration of protein domains of some ECM cell surface molecules. For multichain proteins, only a single subunit is shown. For tenascin, the largest $(230 \mathrm{kDa})$ form is shown. Integrin $\beta 4$ and the F11 receptor have been chosen as examples of the integrin and IgG receptor superfamilies, respectively. Perlecan is given as an example of an extracellular proteoglycan with multiple conserved domains. Fibronectin, tenascin, laminin, collagen, thrombospondin, and perlecan are predominantly ECM molecules, although they are in some cases found associated with cell surfaces.

diversity. Several domain types (FN type III, immunoglobulinlike, EGF-like, thrombospondin type I) are known to mediate cellular interactions (Thiery and Boyer, 1992; Yamada and Kleinman, 1992). FN and tenascin exemplify ECM proteins for which alternate splicing produces different protein forms in different spatial and temporal patterns (Kaplony et al., 1991; Pagani et al., 1991).

Several ECM components are now known to be part of protein families, encompassing several evolutionary related genes. A prominent example is the family of LM-like proteins. LM, a potent stimulator of neurite outgrowth, is composed of a B1, a B2, and an A chain (Reichardt and Tomaselli, 1991). Merosin combines a distinct $A$ chain homolog with $\mathrm{B} 1$ and $\mathrm{B} 2$ to generate a novel form, which also promotes neurite outgrowth, but has a different spatial and temporal expression than LM (Engvall et al., 1992). S-laminin, which contains a different Bl chain, has yet another pattern of expression, and although it is adhesive for motor neurons, it does not stimulate neurite outgrowth (Hunter et al., 1989b, 1991). With several possible homologs of each chain and multiple combinations of $\mathrm{B} 1, \mathrm{~B} 2$, and $\mathrm{A}$ homologs, the number of LM-like proteins may be quite large. Tenascin is another ECM component that represents a protein family. Tenascin (also known as cytotactin, $\mathbf{J} 1$ glycoprotein, hexabrachion, myotendinous antigen, and glioma mesenchymal ECM antigen) is present in many tissues and exists in alternatively spliced forms (Jones et al., 1989; Spring et al., 1989). A related gene codes for $\mathrm{J} 1-160 / 180$, also known as janusin (Peshava et al., 1989), and a third form, restrictin, is expressed only in neural tissues (Norenberg et al., 1992). Since these proteins have multiple domains with adhesive and antiadhesive effects, the tenascin family may play many different roles.

ECM components can also exist as cell surface components, as in the case of several members of the immunoglobulin superfamily. These molecules can be bound to cell surfaces by a glycosylphosphatidylinositol (GPI) membrane anchor, and are also released or secreted into the ECM (Sonderegger and Rathjen, 1992). Neural cell adhesion molecule (NCAM) typifies a cell surface adhesion component that also exists extracellularly, in cerebrospinal fluid, and also associated with ECM components (He et al., 1987). Similarly, the isotypes chick axonin 1/rat TAG-1 and chicken F1 1/mouse F3 exist in multiple forms (Durbec et al., 1992). There may be great diversity of interactions involving these glycoproteins, since several bind in both a homophilic and heterophilic manner to components of cell surfaces 
and ECM (Kuhn et al., 1991; Stoeckli et al., 1991; Sonderegger and Rathjen, 1992).

\section{Spatial and temporal distribution of ECM components in developing neural tissues}

Immunohistochemistry and in situ hybridization with nucleotide probes have been used to examine the spatial and temporal expression patterns of ECM components in developing neural tissues, especially in regions of cell movements. These studies have shown that there is abundant ECM in the CNS and PNS, at times when neurons differentiate and migrate, and axons elongate. This ECM is transiently present, and it is substantially reduced by the end of development. Although the presence of ECM is clearly widespread, not all ECM components have been localized, and not all regions and stages have been surveyed in any one species.

The complexity of the extracellular environment is revealed by examining the expression patterns of several ECM components in a single region over the course of development. For example, the developing subplate of the mammalian telencephalon is a transient layer, containing extracellular space through which neurons and growth cones migrate (Shatz et al., 1990). This region has a complex ECM, which includes FN, LM, chondroitin sulfate proteoglycan (CSPG), and S-laminin (Sheppard et al., 1991; Hunter et al., 1992a). The combination of immunohistochemical evidence from embryonic tissues and immunocytochemical and biochemical studies of cultured cells suggests that embryonic glia synthesize most or all of this transient ECM. In the developing spinal cord a variety of ECM components and cell adhesion molecules, LM, S-laminin, collagen IV, heparan sulfate proteoglycan (HSPG), F-spondin, L1, F11, $\mathrm{N}$-cadherin, neurofascin, and TAG-1, are distributed in a complex spatial and temporal pattern (Shiga and Oppenheim, 1991; Klar et al., 1992). Growth cones that migrate in this environment encounter surfaces expressing diverse molecules, depending on neuronal type, pathway, and developmental stage. Several ECM components, including S-laminin, F-spondin, and tissue plasminogen activator, reach their highest expression in the floor plate, a region that may be critical in spinal cord growth cone navigation (Hunter et al., 1992a; Klar et al., 1992; Sumi et al., 1992).

Another way to examine the pattern of ECM expression is by localizing a single ECM component in different regions and developmental periods. Comparison of the results may suggest roles that are played by a particular component. The LM homo$\log$ S-laminin was discovered by virtue of its restricted presence in the neuromuscular synaptic basal lamina, as distinct from LM, which is present throughout the muscle basal lamina (Hunter et al., 1989a,b). In the telencephalic subplate, the neural retina, and the spinal cord, the distribution of S-laminin is more spatially and temporally restricted than that of LM (Hunter et al., 1992a,b). These differential patterns of S-laminin deposition suggest that its functions are distinct from those of LM. For cxamplc, while LM stimulates neurite elongation, S-laminin may promote the cessation of neurite elongation before synaptogenesis at motor end plates, and in the neural retina LM and S-laminin may have distinct effects on differentiation of the various retinal cell types.

Immunohistochemical studies of the distribution patterns of tenascin indicate that, unlike S-laminin, it is broadly expressed in developing tissues (Chiquet-Ehrismann, 1990). The roles of tenascin are uncertain. One reason for this uncertainty arises from comparisons of immunohistochemical staining of different developing neural tissues. In the cerebral cortex tenascin may not be involved in neuronal migration or axonal growth, since it does not appear until after cortical layers and axonal pathways are established (Sheppard et al., 1991). However, in the postnatal cerebellar cortex, tenascin is present when parallel fibers are elongating throughout the molecular layers (S. Bartsch et al., 1992). In the mouse, tenascin is present in the optic ncrve and in peripheral nerves at the time axons are growing (U. Bartsch et al., 1992). Yet, tenascin is reported absent from both the early limb mesenchyme in regions penetrated by the first axons (Wehrle-Haller et al., 1992) and from the developing chick optic nerve (Perez and Halfter, 1993). Uncertainty about the role of tenascin also comes from in vitro studies that report tenascin can both promote and inhibit neuronal migration and neurite elongation (Faissner and Kruse, 1990; Wehrle and Chiquet, 1990; Chiquet-Ehrismann, 1991; I ochter et al., 1991). These diverse reports suggest that tenascin modulates axonal growth, but the mechanism is unclear.

Studies of the distribution patterns of ECM components have also been carried out with invertebrate embryos (reviewed by Fessler and Fessler, 1989; Hortsch and Goodman, 1991). Invertebrate homologs of collagen IV, LM, tenascin, and vitronectin have been described in animal systems where genetic approaches can be applied to reveal functions of these known ECM components in neuronal morphogenesis (Kusche-Gullberg et al., 1992; Mirre et al., 1992; Nakashima et al., 1992; Baumgartner and Chiquet-Ehrismann, 1993; Henchcliffe et al., 1993). In addition, studies of invertebrates may lead to discovery of novel ECM components. For example, three monoclonal antibodies label the ECM of cmbryonic inscct legs in a graded, nonuniform distribution (Norbeck et al., 1992), indicating that the protein antigens are present in spatial and temporal distribution patterns that make them candidates for substratum-bound axon guidance cues.

\section{Functions of ECM components in neuronal development}

In vivo approaches. These in vivo palterns of ECM distribution and expression indicate that many ECM components are present where they could modulate cell migrations and neurite growth. Until recently, attempts to identify the functions of ECM components in vertebrate neural development have mostly involved injecting antibodies and other reagents into avian and amphibian embryos, or exposing semiintact preparations, such as tissue slices, to these agents in culture. The results obtained include disruptions of neural crest cell migration in avian embryos (Bronner-Fraser, 1986, 1987; Bronner-Fraser and Lallier, 1988; Bronner-Fraser et al., 1992b), inhibition of granule cell migration along glial fibers in cerebellar explants (Choung et al., 1987; Liesi et al., 1992), and abnormal patterns of regeneration at neuromuscular junctions (Mège et al., 1992). In contrast, injections of anti-LM into avian embryos did not lead to any observable defects in the projection of sympathetic preganglionic axons (Yip and Yip, 1992).

Some of these findings implicate particular molecules, such as LM and tenascin, in cell migration and axon elongation, but how do injected antibodies disrupt morphogenetic cell movements? Do injected antibodies directly block a migratory mechanism, or is the disruption more indirect? For example, do the antibody molecules bind to a molecule that is not normally involved in the process, thereby sterically blocking a nearby, but distinct, interaction that is involved in migration? Or does 
antibody-induced disruption of cell-ECM interactions prompt a cascade of changes that indirectly disrupts nerve cell or growth cone migration?

This concern about the ambiguity of results obtained by use of antibodies has been addressed by a recently developed technique, chromophore-assisted laser inactivation (CALI), which uses a laser beam to inactivate a protein by high-energy transfer from a fluorochrome-conjugated antibody, bound to the protein. Using this technique, Jay and colleagues (Jay and Keshishian, 1990; Schnipper ct al., 1992) have presented results indicating that inactivation of particular axonal surface molecules, fasciclin I and fasciclin II, disrupts the stereotypic outgrowth of grasshopper pioneer axons. Application of CALI to focal areas of embryos or semiintact preparations would permit a precisely controlled inactivation of a specific ECM component in a particular region of cell migration or neurite elongation.

Another technique that has come into use for probing the functions of ECM components in mammals is their deletion by gene knockout. Genetically engineered mice lacking the tenascin gene developed normally without obvious defects (Saga et al., 1992). Notwithstanding the possibility of subtle defects, these results would indicate that tenascin is not essential for normal development (Erickson, 1993). It is possible, of course, that in the mutant mice the essential functions of tenascin, if any, are replaced by another member of the tenascin family, or that bypass mechanisms exist to ensure normal development in cases of accidental dysfunction.

Invertebrate species have also been used to investigate the roles of ECM components in neural development. A mutation in the gene unc- 6 of the nematode Caenorhabditis elegans disrupts circumferential axonal projections, but longitudinal projections are unaffected (Ishii et al., 1992). The sequence of the unc- 6 protein most closely resembles the LM B2 chain, and it is proposed that unc- 6 codes for an ECM component of the epidermal basal lamina that is part of a dorsoventral axonal guidance system. As discussed below, another gene, unc-5, may code for a plasma membrane receptor for ECM proteins.

In vitro approaches. In vitro studies can directly probe whether an ECM molecule supports particular types of cell migration or axonal elongation. On the basis of such studies, thrombospondin, vitronectin, F-spondin, and the $\mathrm{NCl}$ domain of type IV collagen have been included among ECM molecules that promote neurite outgrowth (Lein et al., 1991; Neugebauer et al., 1991; O'Shea et al., 1991; Klar et al., 1992; Osterhout et al., 1992). Synthetic peptides and epitope-specific antibodies can probe neural interactions with individual structural domains of ECM components. For example, the adhesive and antiadhesive effects of different domains of tenascin have been identified, as well as the specific domains of tenascin that interact with different nerve cell types (Lochter et al., 1991; Husmann et al., 1992; Prieto et al., 1992). Synthetic peptides have been used to mimic individual structural domains of ECM proteins (Yamada and Kleinman, 1992). Neurite outgrowth is promoted on substrata treated with any of two heparin-binding and two potential $\beta 1$-integrin-binding peptides from the carboxyl-terminal globular domain of the LM A chain (Skubitz et al., 1991). An arginine-glycine-aspartate-containing peptide of the A chain also promotes neurite outgrowth (Tashiro et al., 1991), and leucinearginine-glutamate (LRE) sequence in LM and S-laminin may be a specific adhesive site for motor neurons (Hunter et al., 1991). A heparin-binding peptide and a potential integrin-binding peptide from the carboxyl terminus of FN support neurite outgrowth from spinal cord and sensory neurons (Haugen et al., 1992b). While this approach has identified potential functional domains, a strong possibility of artifacts exists. For example, the cell binding activity of heparin-binding peptides may be nonspecific ionic binding of negatively charged surface components to clustered, positively charged residues of the synthetic peptide. As another example of results with uncertain significance, the binding of neurons to the LRE peptide of LM and $\mathrm{S}$-laminin occurs without the presence of extracellular $\mathrm{Ca}^{2+}$, but does not occur at physiological levels of extracellular $\mathrm{Ca}^{2+}$. The challenge is to devise experiments that demonstrate that a peptide sequence of interest actually participates in neuronal interactions with an intact ECM molecule.

In vitro studies suggest that adhesivity is not the only factor to consider in understanding how the multiple domains of $\mathrm{ECM}$ components regulate neural cell and growth cone migrations (Lein et al., 1992). For instance, when retinal neurons are grown on substrata treated with LM and the adhesive cell surface molecules L 1 and N-cadherin, no clear relationship is found between substratum adhesivity and growth cone shape, elongation rate, or neurite fasciculation (Lemmon et al., 1992). As another example, olfactory neurons, when presented a choice of migrating on FN or LM, prefer to migrate on LM. It is unknown whether this reflects a preference for a particular level of adhesivity or some other aspect of the neuronal interaction with LM. The existence of nonadhesive or even antiadhesive neuronal interactions with LM is indicated by the finding that neuronal adhesion to an FN-treated substratum is much reduced by the addition of as little LM as 1 part in 50 (Calof and Lander, 1991). The immunoglobulin superfamily member F3/F11, which is expressed both bound to cell surfaces and in soluble form, is also intriguing in the diversity of its in vitro effects. In soluble form it promotes neurite outgrowth (Durbec et al., 1992). On neuronal surfaces F3/F11 binds several members of the tenascin family (tenascin, J160/180, and restrictin), and mediates the initial adhesion of neurons to a $\mathrm{J} 1-160 / 180$ substratum, followed by release of the neurons from the substratum (Zisch et al., 1992; Pesheva et al., 1993). These diverse responses show how the interactions of multiple neuronal surface components with several functional domains of an ECM component can lead to cascades of effects on cell behavior (Damsky and Werb, 1992; Schweighoffer and Shaw, 1992).

\section{Cell Surface Receptors of ECM Components}

The precise spatial and temporal distributions of both growthpromoting and growth-inhibiting ECM components are likely to play an important role in determining patterns of neuronal migration and neurite outgrowth during development. Equally important may be the distribution of cell surface receptors for ECM components on different classes of neurons that confront the same extracellular environment, or on the same class of neurons at different stages of their development. Different types of neurons will extend axons to different ultimate destinations in the embryo through roughly the same initial embryonic terrain. Regulation of receptor expression or modulation of receptor function in different classes of cmbryonic neurons could potentially generate unique profiles of affinity for extracellular molecules that contribute to the precise patterns of neural cell and growth cone migration seen in vitro. Several recent reviews have dealt with cell surface receptors for ECM components (Damsky and Werb, 1992; Ginsberg et al., 1992; Hynes, 1992; Schweighoffer and Shaw, 1992), and specifically with those re- 


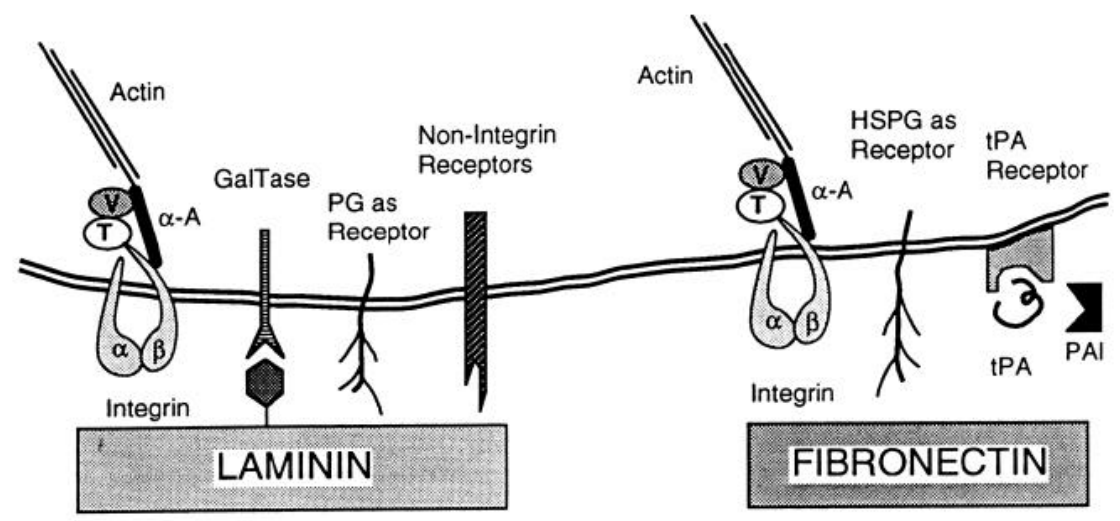

Figure 2. The cell surface proteins mediating cellular interactions with laminin (LM) and fibronectin (FN). Integrin $\alpha \beta$-heterodimers recognize both LM and FN and transduce information to the cytoskeleton. The actin cross-linking protein $\alpha$-actinin $(\alpha-A)$ binds to the cytoplasmic domain of the integrin $\beta$-subunit, as does talin (T), although with lower affinity. Talin binds vinculin $(V)$, which in turn also binds $\alpha$-actinin. Galactosyltransferase (GalTase) acts as a receptor for LM carbohydrate residues. Cell surface proteoglycans $(P G)$ may also bind extracellular LM. A variety of nonintegrin laminin receptors have been described (for review, see Mecham, 1991). Heparan sulfate (HS) is known to bind FN, and cell surface HSPG may act as a FN receptor. Tissue plasminogen activator $(t P A)$ associates with the cell surface via a high-affinity tPA receptor. Neuronally derived plasminogen activator (PA)-like proteases have been shown to degrade FN. Target-derived soluble and substrate bound inhibitors (PAI) regulate PA activity.

ceptors found in the nervous system (de Curtis, 1991; Reichardt and Tomaselli, 1991; Hynes and Lander, 1992; Letourneau et al., 1992). Here, we present recent findings involving neuronal receptors of ECM components.

\section{Integrins}

Distribution of integrins during development and regeneration. Members of the $\beta 1$-integrin family are the best-characterized neuronal receptors for ECM components (Fig. 2; Hynes and Lander, 1992. However, our understanding of the spatial and temporal distribution of integrins in vivo is limited due to the lack of reagents that adequately distinguish the various representatives of the $\beta 1$ class. Antibodies that are specific for different $\alpha$-integrin subunits have recently allowed the distribution of several integrins to be characterized in the nervous system. In adult avian tissues the $\alpha 1 \mathrm{LM} /$ collagen receptor is restricted to smooth muscle and capillary endothelial cells, yet during stages of active neurite outgrowth it is transiently expressed in portions of both the CNS and PNS (Duband et al., 1992). The $\alpha 6 \mathrm{LM}$ receptor is also developmentally regulated, although its distribution is somewhat broader and less temporally restricted than that of the $\alpha 1$ subunit. Integrin $\alpha 6$ expression is noticeably more abundant on subpopulations of spinal neurons, particularly commissural axons and cell bodies (Bronner-Fraser et al., 1992a). While the $\alpha 5$ FN receptor is apparently not expressed by developing chick neuronal cells (Muschler and Horwitz, 1991), it has been implicated in axon outgrowth during regeneration. Both the $\alpha 5 \beta 1$ receptor and FN are strongly induced following injury in neuronal and non-neuronal cells of chick peripheral nerve (Lefcort et al., 1992). While these studies do not directly address the function of integrins in neuronal development, their temporal and spatial expression patterns are suggestive of the roles integrins may play. In contrast to the ubiquitous distribution of the $\beta 1$ subunit during development, specific $\alpha$-subunits seem ideally situated to mediate axon outgrowth and regeneration in particular subpopulations of neurons. The restricted spatial distributions of different integrins may account for recent observations indicating that there are different surface components that mediate cell-substratum interactions in comparisons between central and peripheral neurons (Haugen et al., 1992a) and between cranial and trunk neural crest cells (Lallier et al., 1992).

Regulation of integrin expression and function. The expression of integrins and their affinity for ligands are influenced by many factors, including cytoplasmic activators and repressors, cellsurface modulators, and ECM components (reviewed in Damsky and Werb, 1992; Ginsberg et al., 1992; Hynes, 1992; Schweighoffer and Shaw, 1992). Most of these factors have been described for cells of the hemopoietic system. Although mechanisms of receptor modulation are likely to apply generally to members of the integrin class, there is little specific information concerning modulation of integrin function in neuronal cells. Recently, it was found that $\alpha 1 \beta 1$-integrin of neural crest cells binds in the absence of divalent cations to LM substrata prepared in the presence of calcium. In contrast, neural crest cells require the presence of divalent cations for binding to LM substrata prepared in the presence of EDTA, heparin, magnesium, or manganese, and adhesion to LM under these conditions appears to be mediated by a non- $\alpha 1$-integrin receptor (Lallier and Bronner-Fraser, 1992). These data suggest that the conformation of LM can be affected by the concentration of divalent cations available in the extracellular space during its deposition, and that differences in LM conformation can alter both the receptor specificity and the cation dependence of subsequent integrin binding. The potential importance of cation-dependent/ independent integrin function is suggested by the observation that cranial and trunk neural crest cells employ different integrins with different cation dependence to interact with LM, FN, and collagens I and IV (Lallier et al., 1992). Such differences in integrin specificity and function could underlie the differences in migration pathway choices made by these two classes of neural crest cells.

The construction and expression of chimeric or truncated molecules has been a useful approach to determining the function of integrins (Hibbs et al., 1991; Dana et al., 1991; Solowska et al., 1991). In a recent study, chimeric cDNAs consisting of the extracellular and transmembrane domains of the $\alpha 2$ collagen/LM receptor and the intracellular domains of the $\alpha 5$ and $\alpha 4$ FN receptors were expressed in rhabdomyosarcoma cells. All the chimeric receptors tested support cell attachment to 
collagen and LM in short-term cell adhesion assays. Yet, there are marked differences in the ability of the various cytoplasmic domains to support specific cell behaviors (cell spreading, migration, and exertion of sustained force) that are thought to depend on cell-substratum adhesion (Chan et al., 1992). These results indicate that cell-substratum attachment, as measured by a standard cell adhesion assay, may only poorly reflect the ability of a receptor to mediate cell behaviors that are important during development. Moreover, these results suggest that the highly conserved cytoplasmic domains of integrin $\alpha$-subunits may interact with intracellular components in distinctly different manners to generate various types of "adhesive" cell behaviors.

There have been few analyses of integrin function in vivo. Antibody perturbation studies indicate a role for $\beta 1$-integrins in neural crest cell migration (Bronner-Fraser, 1986), and genetic analysis has shown that integrins are required for several aspects of Drosophila development (Leptin et al., 1989; Zusman et al., 1990, 1993). A recent promising approach of Galileo et al. (1992) uses a retroviral vector to introduce integrin antisense mRNA into early neuroblasts of avian optic tectum. In cultured cells, this treatment reduces the levels of $\beta 1$-integrin expression by $40-60 \%$. In embryos, reduction of $\beta 1$-integrin expression in the carly stages of neuroblast proliferation and migration has profound effects on subsequent development. Integrin-depleted clonal cohorts remain in the ventricular zone, failing to migrate into the tectal plate, and appear to be eliminated eventually. These results suggest that integrin-mediated processes are required for neuroblast migration and that a direct or indirect consequence of integrin depletion is cell death.

\section{Nonintegrin $L M$ receptors}

Cell surface $\beta 1,4$-galactosyltransferase (GalTase) is an LM receptor found in a variety of cell types, including neural crest (Runyan et al., 1986), PC12 cells (Begovac and Shur, 1990; Begovac et al., 1991), and primary sensory neurons (Riopelle and Dow, 1991). GalTase mediates cell attachment and migration by binding to terminal $N$-acetylglucosamine residues within the E8 domain of LM (Begovac and Shur, 1990). In a recent study of Hathaway and Shur (1992), the role of GalTase in neural crest migration in vivo was examined. GalTase is present on migrating crest cells and the basal surfaces of neural epithelia. Injection of anti-avian GalTase antibodies into early chick embryos results in specific defects of neural development: neural fold elevation and neural tube closure are perturbed and neural crest migration is delayed. Similar defects in neural tube closure and neural crest migration are observed in chick embryos after the injection of antibodies directed against $\beta 1$-integrin (BronnerFraser, 1986), the HNK-1 carbohydrate moiety (Bronner-Fraser, 1987), tenascin (Bronner-Fraser, 1988), LM/HSPG complex (Bronner-Fraser and Lallier, 1988), and the cell adhesion molecules NCAM and N-cadherin (Bronner-Fraser et al., 1992b), suggesting that these elements of neural crest development are particularly sensitive to disruption of cell-cell and cell-substratum interactions.

Nonintegrin cell surface molecules capable of binding to LM affinity columns and potentially mediating cell interactions with LM have been described (reviewed in Mecham, 1991). One such protein, the $67 \mathrm{kDa}$ elastin/LM receptor, binds $\mathrm{LM}$ with high affinity and is found on a variety of migratory cell types (particularly tumor cells), including some neuron cells (G. Yang et al., 1992). While the distribution pattern of this molecule and its biochemical properties are consistent with its proposed function as a LM receptor, cloning of the gene has proven to be difficult. Several attempts have been made to isolate cDNA clones, either with expression library screening using antibodies against the protein or with degenerate oligonucleotide probes based on peptide sequence from the purified molecule. These attempts have identified a highly conserved 1.3 kilobase $(\mathrm{kb})$ transcript that predicts a protein of roughly $33 \mathrm{kDa}$ without a signal sequence or transmembrane domain (see, e.g., Grosso et al., 1991). Based on inferred peptide sequence (Grosso et al., 1991) or biochemical analysis (Auth and Brawerman, 1992), the $33 \mathrm{kDa}$ protein appears to be cytoplasmic, possibly a component of polyribosomes. However, a 20 amino acid synthetic peptide derived from the sequence of the $33 \mathrm{kDa}$ protein does specifically bind LM with high affinity (Castronovo et al., 1991), suggesting that the protein may share functional or at least structural similarity with the $67 \mathrm{kDa}$ cell surface LM-binding protein.

The possibility of shared structural/functional homology between cell surface LM-binding proteins and "unrelated" cytoplasmic proteins is further illustrated by a second example, that of the $120 \mathrm{kDa}$ LM-binding protein termed "crainin" (Smalheiser and Collins, 1992a,b; Smalheiser et al., 1992). Crainin binds to LM in a divalent cation-dependent manner and bears the HNK-1 epitope. Antibodies against crainin label cells undergoing axonogenesis and regenerating optic fibers. Crainin shows significant biochemical similarity and overlapping distribution with another neuronal LM-binding protein, termed the $110 \mathrm{kDa}$ LM-binding protein, and the two proteins are likely to be related (Pomeranz et al., 1991). The first 18 amino acids of the $110 \mathrm{kDa}$ protein are virtually identical to nucleolin, a nucleolar phosphoprotein involved in ribosome biogenesis (Kleinman et al., 1991).

\section{Other putative ECM-binding proteins}

The gene encoding a $30 \mathrm{kDa}$ heparin binding protein, amphoterin, has been cloned from rat brain (Merenmies et al., 1991). The function of amphoterin has not been completely analyzed, but several properties of the molecule suggest a role in neurite outgrowth. Antibodies against amphoterin block neurite outgrowth by neuroblastoma cells on LM when added in solution and promote neurite outgrowth when plated as a substratum. Amphoterin colocalizes with tissue plasminogen activator (tPA) in filopodia and binds to both plasminogen and tPA in vitro. Binding of amphoterin to either tPA or plasminogen accelerates tPA-catalyzed plasminogen activation about 50-fold (Parkkinen and Rauvala, 1991). Since numerous proteases degrade ECM componcnts, amphotcrin's cffects on tPA may facilitate mechanical penetration of the ECM by growing axons. Alternatively, amphoterin may indirectly influence neurite outgrowth by accelerating proteolytic activation of growth factors that are sequestered in the ECM. Neural crest cells, for example, secrete an inactive form of transforming growth factor $\beta$ (TGF- $\beta$ ) that can be activated by a urokinase-like plasminogen activator aclivity released from migrating neural crest cells (Brauer and Yee, 1993). Activated TGF- $\beta$ influences the timing of neural crest migration and the adhesion of neural crest cells to ECM components (Delannet and Duband, 1992). Recently, it has been shown that amphoterin also binds the cell surface HSPG syndecan [the low-affinity receptor for basic fibroblast growth factor (bFGF)], and that this interaction can be inhibited by heparan sulfate (HS) and heparin (Salmivirta et al., 1992).

In the nematode, the $u n c-5$ gene is required for the proper 


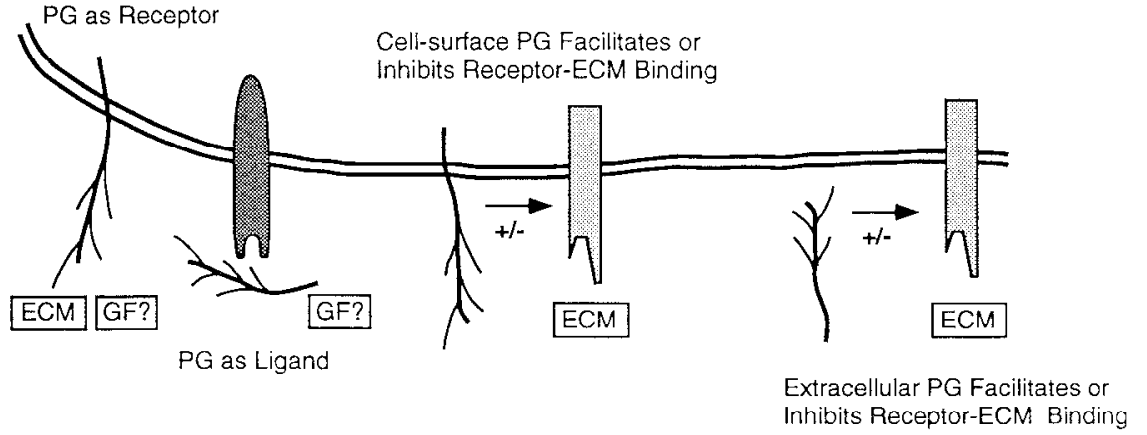

Figure 3. The possible mcans by which proteoglycans $(P G)$ could mediate cellECM interactions. Cell surface-associated PG could act as a receptor for extracellular molecules, including growth factors $(G F)$. PGs can be associated with the cell surface either as membrane proteins or via receptors that bind either the PG core protein or GAG side chains. Extracellular PGs could themselves be ligands for cell surface receptors for FCM components. PGs at the cell surface can interact with matrix receptors to facilitate or inhibit cell-matrix binding. In an analogous fashion, cxtracellular PGs can interact with ECM proteins to facilitate or inhibit their binding to cell surface receptors. migration of cells during development and the correct guidance of pioneer axons (Hedgecock et al., 1987). The unc-5 gene has been cloned and was found to code for a transmembrane receptor-like protein with both immunoglobulin and thrombospondin type 1 domains. The molecule is expressed in migrating cells and pioneer neurons, and seems likely to function as an ECM component receptor (Leung-Hagensteijn et al., 1992). Misexpression of the unc- 5 protein in six identified touch receptor neurons is sufficient to misdirect the axons of these cells along a dorsal route similar to that taken by motor neurons endogenously expressing $u n c-5$. The effect of unc-5 misexpression on axon outgrowth is dependent on unc-6, an LM-like ECM molecule that has been proposed as the ligand for $u n c-5$ (see above); in the absence of $u n c-6, u n c-5$ misexpression alone is not sufficient to misroute touch receptor neurons dorsally (Hamelin et al., 1993). These results strongly suggest that the LMlike molecule encoded by the unc- 6 gene is the ligand for the unc -5 receptor. Moreover, these results provide the first evidence for the widely accepted notion that the route taken by a growing axon is determined by the specific receptors cxpressed by that cell.

Several neuronal receptor-like protein tyrosine phosphatase (PTP) genes in Drosophila have recently been characterized (Tian et al., 1991; Yang et al., 1991). The deduced proteins contain extracellular FN type III repeats and intracellular PTP domains. The expression of these genes is initially restricted to the axons and growth cones of early arising pioneer neurons. Although the function of these molecules is unknown, Yang et al. (1991) proposed a model for modulation of growth cone guidance by cell surface receptor-PTPs based on the observation that dephosphorylation increases the activity of some tyrosine kinases, for example, pp60 ${ }^{\mathrm{c}-\mathrm{src}}$. A receptor PTP could potentially regulate growth cone morphology by locally activating a kinase that in turn phosphorylates tubulin monomers, thereby inhibiting microtubule polymerization.

\section{Proteoglycans in the Nervous System}

PGs, a class of glycoproteins that have a high content of glycosaminoglycans (GAGs), are present not only as ECM components, but also in cell surface, membrane-spanning (Nishiyama et al., 1991), soluble (Andres et al., 1989), and intracellular forms (Aquino et al., 1984; Rauch et al., 1991). Due to the large number of PG species and their low concentrations, and to problems of fixing, staining, isolating, and purifying PGs, it has been difficult to characterize them until recently. However, monoclonal antibody and molecular biological techniques have opened new avenues for the exploration of PGs and produced an explosion of information concerning PG localization, interactions, and functions in the nervous system (Fig. 3). PGs have been implicated in the regulation of cell morphology (Leppa et al., 1992), cell adhesion (Bidanset et al., 1992; Drake et al., 1992; Faassen ct al., 1992; Iida et al., 1992; Minguell ct al., 1992), migration (Perris et al., 1991), proliferation (Ratner et al., 1988; Wright et al., 1989), differentiation (Trautman et al., 1991), cell-cell and cell-ECM interactions (P. Yang et al., 1992), neuronal polarity (LaFont et al., 1992), growth factor binding and presentation (Walicke, 1989; Turnbull et al., 1992), signal transduction (Nishiyama et al., 1991), synapse stabilization and organization of adult brain (Hockficld et al., 1990; Fryer et al., 1992; Rauch et al., 1992), and neurological disorders (Shioi et al., 1992). Given the complexity and diversity of PG structure (Margolis and Margolis, 1989; Ruoslahti, 1989; Schwartz and Smalheiser, 1989; Jackson et al., 1991), the functions of PGs are likely determined by many factors, including the molecules with which they interact, their spatial and temporal expression, and whether cells respond to the protein core of the $\mathrm{PG}$, to the GAGs, or to both.

\section{PGs of the ECM}

Positive influence of PGs on axon outgrowth. Certain PGs can either be permissive for (allow but not actively stimulate), or promote (actively stimulate) neuronal elongation (Davis et al., 1985; Hantaz-Ambroise et al., 1987; Dow et al., 1991; Iijima et al., 1991; Noonan et al., 1991; Sheppard et al., 1991; Shiga and Oppenheim, 1991; Haugen et al., 1992b; Johnson-Green et al., 1992; Snow and I etourneau, 1992). For instance, astrocytes, which provide a substratum to which nerve cells attach and elongate in vivo and in vitro, express a number of PGs on their cell surface and also secrete them into the extracellular environment (Johnson-Green et al., 1991). Of these, only HSPG enhances neurite outgrowth by sensory neurons on LN (Johnson-Green et al., 1992).

Both heparin and HSPG are necessary for axon guidance in the cockroach. Of six axon pathways analyzed, only the median fiber tract of the CNS, a homolog to the MP4 midline precursors in the grasshopper (Goodman and Schatz, 1993), and the pathway of the Til neurons of the PNS (Bate, 1976) are altered by exogenous heparin and $\mathrm{HS}$ or by treatment with heparinase II and heparitinase (Wang and Denburg, 1992). This alteration is 
characterized by inappropriate pathfinding in both pathways and by reduced fasciculation in the Til pathway. Addition of other GAG moieties such as chondroitin sulfate (CS) A and C, dermatan sulfate (DS), hyaluronic acid, and keratan sulfate (KS) did not alter the outgrowth pattern.

Another cell surface component, possibly a PG, important in insect axon guidance is anchored by GPI (Chang et al., 1992). Treatment of grasshopper embryos with bacterial phosphatidylinositol-specific phospholipase C (PI-PLC), which cleaves the GPI anchor, causes a significant perturbation of highly stereotyped outgrowth of pioneer axons. Treatment with PI-PLC removes fasciclin I immunoreactivity and may also remove GPI-anchored PGs (Drake et al., 1992).

PGs as inhibitors of axon outgrowth. Certain PGs either actively inhibit, or are non-permissive substrata for, neurite outgrowth (Carbonetto et al., 1983; Akeson and Warren, 1986; Damon et al., 1988; Muir et al., 1989; Verna et al., 1989; Snow et al., 1990a,b, 1991; Cole and McCabe, 1991; Fichard et al., 1991; McKeon et al., 1991; Oakley and Tosney, 1991; Oohira et al., 1991; Brittis et al., 1992; Snow and Letourneau, 1992), as well as for neural crest migration (Perris and Johansson, 1990; Perris et al., 1991). These PGs are often concentrated where axons do not grow in vivo (Snow et al., 1990b; Cole and McCabe, 1991; Brittis et al., 1992). In chick, a CSPG is expressed in the posterior sclerotome, the perinotochordal mesenchyme, and the pelvic girdle, all of which are regions that axons avoid as they elongate toward the hindlimb (Oakley and Tosney, 1991). Moreover, the expression of a CSPG is spatially and temporally regulated in the rat and chick retina and may direct retinal ganglion cell (RGC) axons toward the optic fissure by means of axon inhibition (Snow et al., 1991; Brittis et al., 1992). However, several PG types are expressed in the RGC layer where axons elongate (Halfter, 1992), in the photoreceptor layer (Landers and Hollyfield, 1992), in the optic nerve (Geisert et al., 1992), or by glial-like cells in the retina (Threlkeld et al., 1989), supporting the possibility of a multifunctional role for PGs in optic system development.

Keratan sulfate proteoglycan (KSPG) plays an inhibitory role in the guidance of elongating axons (Snow et al., 1990a,b; Wu et al., 1991). A KSPG, claustrin, isolated from embryonic chick nervous system, abolishes neurite outgrowth on growth-promoting substrata (Cole and McCabe, 1991). Two additional lines of evidence suggest that claustrin may be an inhibitor of neurite outgrowth in vivo. First, claustrin is expressed in vivo in regions, such as the dorsal midline, which have been shown previously to act as a barrier to growth cone advance (Snow et al., 1990b; Wu ct al., 1992). Sccond, cnzymatic removal of KS from the KSPG molecule in vitro renders the $P G$ permissive for axon outgrowth (Snow et al., 1990a).

Although many examples exist of PGs inhibiting neurite outgrowth, the mechanism(s) of inhibition is yet undefined. Recent data show that contact with CSPG raises intracellular calcium levels in growth cones. Thus, inhibition of growth cone advance may occur via this second-messenger pathway. A rise in growth cone calcium is not observed after enzymatic removal of the carbohydrate moiety, suggesting that this portion of the $P G$ is responsible for inhibition of axon elongation (Snow et al., 1993).

$P G s$ and neuronal polarity. Neurons are morphologically and functionally polar cells, having distinct axonal and dendritic processes (Goslin and Banker, 1989; Lein et al., 1992). PGs may be among the factors regulating the development of polarity in neurons. LaFont et al. (1992) have shown that CS and HS en- hance axonal outgrowth, while DS stimulates dendritic growth. DS selectively enhances neuronal adhesion and spreading concomitant with abundant expression of the dendritic marker microtubule-associated protein-2 (MAP2). Similarly, CSPG may regulate axonal initiation by RGCs (Snow et al., 1991; Brittis et al., 1992).

\section{PGs at the cell surface}

Thus far, we have considered the roles of ECM- and cell-associated PGs in nervous system development. PGs are expressed also on the cell surface, where they may function as receptors for ECM components (Rapraeger et al., 1986; Hoffman et al., 1988), bind growth factors (Jackson et al., 1991; Thiery and Boyer, 1992), and mediate adhesion (Lewandowska et al., 1987; Hynes and Lander, 1992). HSPGs deserve special mention since (1) they act as a cell surface receptor for ECM components via their membrane- and matrix-anchoring domains within their protein core (Drake et al., 1992), (2) they bind growth factors (Andres et al., 1992), (3) they are involved in cell-cell and cell-substratum interactions (Haugen et al., 1990, 1992b; Kallapur and Akeson, 1992), and (4) their expression is spatially and temporally regulated (David et al., 1992).

$P G s$ as cell surface receptors. To date, the best-characterized cell surface $P G$ receptor of ECM components is syndecan, an HS/CS-containing integral membrane PG, first described as a surface component of mouse mammary epithelial cells (Saunders and Bernfield, 1988; Bernfield et al., 1992). Syndecan is associated with the intracellular actin cytoskeleton (Rapraeger et al., 1986). Syndecan was initially thought to be restricted to epithelial cells and lymphocytes. However, recent analysis indicates that a putative member of the syndecan family, N-syndecan, is expressed by Schwann cells and in the CNS (Carey et al., 1992). N-syndecan expression is more abundant in neonatal than in embryonic or adult rat brain. Although $\mathrm{N}$-syndecan shows limited homology to syndecan in the membrane-spanning domain, much of the molecule is not homologous to any known protein and a large segment of the gene encoding the extracellular domain has not been cloned. Thus, the importance of N-syndecan as a nervous receptor for ECM components is unclear.

$P G$ binding of growth factors. The binding of growth factors to $\mathrm{PGs}$ has the potential for regulation of cell behavior (Walicke, 1989; Katoh-Semba et al., 1992). Acidic and basic FGF, for example, bind to heparin and HSPG, with HS appearing to act as a cofactor for binding of FGF to its cellular receptor (Yayon et al., 1991). Heparin and HSPGs may protect FGF from degradation, provide an accessible store of FGF within the ECM or, at the cell surface, may help present growth factors to their appropriate receptors (Hondermarck et al., 1992). Syndecan has been suggested as a low-affinity receptor for bFGF (Hondermarck et al., 1992), facilitating the association of bFGF with its high-affinity receptor (Sutherland et al., 1991). A HS/CSPG, betaglycan, binds TGF- $\beta$ via the core protein, and bFGF by means of its HS chains (Andres et al., 1989, 1992). The binding of growth factors by PGs may also regulate neurite outgrowth, since interactions between bFGF and heparin, $\mathrm{HS}$, or hyaluronic acid promote neurite outgrowth from hippocampal cells in culture (Walicke, 1988).

$P G s$, adhesion, and NCAM. PGs play complex roles in the adhesive interactions of neural cells. Best described are the HSPGs, which facilitate adhesion of many cell types to ECM (Bidanset et al., 1992; Iida et al., 1992; Minguell et al., 1992). Several studies have addressed the mechanisms by which HSPG 
and heparin promote adhesion and neurite outgrowth, and have identified heparin-binding domains of several ECM components (Dow et al., 1991; Noonan et al., 1991; Skubitz et al., 1991; Haugen et al., 1992b).

PGs may also modulate several cell adhesion molecules, including NCAM. For example, the CSPGs 1D1, neurocan, and $3 F 8$, which bind directly to neurons, inhibit homophilic cell binding mediated by NCAM and neuroglia cell adhesion molecule (Ng-CAM; Grumet et al., 1993). Another neuronal CSPG, cytotactin-binding $P G$, associates with cytotactin and may mediate neuron-glia adhesion (Hoffman and Edelman, 1987).

The heparin-binding domain (HBD) of NCAM mediates heterophilic interactions of NCAM with cell surface HSPG. Two neural cell lines, one that expresses NCAM and another that does not, both adhere to a synthetic peptide that contains the amino acid sequence of the HBD of NCAM. A polyclonal antiserum against NCAM does not significantly inhibit cell adhesion to the HBD peptide. However, preincubation of the substratum-bound HBD peptide with heparin causes a significant reduction in adhesion of the cells to the peptide. In addition, inhibition of synthesis of HSPG or removal of cell surface HSPG decreases cell adhesion to the HBD peptide (Kallapur and Akeson, 1992). Taken together, these results indicate that the HBD of NCAM does not mediate homophilic NC.AM interactions, but rather mediates heterophilic interactions by binding to HSPG on the cell surface.

In addition to containing a heparin-binding domain, NCAM incorporates an unusual polysaccharide, polysialic acid (PSA; Rutishauser, 1989; Hekmat et al., 1990; Landmesser et al., 1990; Acheson et al., 1991). PSA is a linear homopolymer that, when hydrated, occupies a large volume and may exert steric effects at the cell surface that regulate interactions between other adhesive receptors. A model to account for the influence of PSA on intercellular space was compiled based on physiochemical measurements of cells, and suggests that changes in PSA on NCAM can alter the distance between apposing cell membranes by $25 \%$. Cell surface-associated HSPG and CSPG did not influence the space between cells, even though these molecules contain large hydrodynamic domains and are more highly negatively charged than PSA (P. Yang et al., 1992). It's temporally and spatially regulated expression during initial motoneuron outgrowth through the limb plexus region is consistent with a role for PSA in axon outgrowth (Landmesser, 1978; Lance-Jones and Landmesser, 1981; Tosney and Landmesser, 1985). PSA is important for sorting of axunal projections in the plexus, but not for selection of the appropriate muscle nerve (Tang et al., 1992).

\section{$P G S$ in disease}

Focus on PGs has expanded to encompass not only the roles played by these molecules in normal physiology, but also the pathology that can result from their abnormal metabolism. Several recent studies have implicated certain PGs in conditions involving aberrant axonal outgrowth, such as in CNS injury, and in the development and progression of Alzheimer's disease (AD).

In a model of injury to adult cerebral cortex in rat (McKeon et al., 1991; Laywell et al., 1992), CSPG and tenascin are colocalized with astrocytes in the developing scar. Scar tissue does not support neurite outgrowth in vitro. Similarly, regenerating nerves stop at the dorsal root entry zone, shown recently to express CSPG (Pindzola et al., 1993). The results of these studies in- dicate that CSPG and/or tenascin may inhibit or modulate outgrowth of CNS axons following injury in vivo.

Recent data suggest that PGs may play a role in the development and pathology of AD. AD is characterized by deposition of $\beta$-amyloid protein in blood vessels, which can form senile plaques that are associated with senile dementia. $\beta$-Amyloid is suspected to arise from aberrant posttranslational proteolytic processing of a transmembrane glycoprotein, the amyloid precursor protein (APP), which has a number of forms that arise from differentially spliced transcripts of a single gene (Golde et al., 1990; Cummings et al., 1992; LeBlanc et al., 1992; Luo et al., 1992; Suzuki et al., 1992). Both membrane-associated and soluble (secreted) forms of APP exist, and one report suggests that APP mediates the promotion of neurite outgrowth by NGF (Milward et al., 1992). Several studies suggest that the membrane precursor for $\mathrm{AD} \beta$-amyloid protein is associated with an HSPG (Schubert et al., 1988; Kalaria et al., 1992; Su et al., 1992). Shioi et al. $(1992,1993)$ report that APP also exists as the core protein of a CSPG secreted from the glial cell line C6. In C6, approximately $90 \%$ of the secreted form of APP occurs in the CSPG form, indicating that CS is likely to play a role in the biological function of the protein. Further, a dermatan sulfate proteoglycan, decorin, exists in amyloid plaques and neurofibrillary tangles of $\mathrm{AD}$ and may be involved in abnormal neuronal growth (Snow et al., 1992).

\section{Conclusion}

Recent evidence has further augmented our awareness of the diversity and complexity of the involvement of the ECM in the movements of cells and growth cones during neural development. It is now clear that ECM components have both stimulatory and inhibitory effects on nerve cell and growth cone migrations, and much remains to be learned about how interactions with the ECM generate transmembrane signals that regulate the cytoskeletal and membrane activities that drive these morphogenetic movements. The application of cellular and molecular approaches has revealed an almost overwhelming number of potential interactions between ECM components and integrins, nonintegrin surface receptors, PGs, adhesive glycoproteins, proteases, and other ECM components. Future work will seek to elucidate the molecular domains that regulate and mediate the interactions of ECM components and cell surface molecules. Ultimately, the interactions of nerve cells with the ECM must be revealed in vivo, and so it augurs well that multidisciplinary strategies, involving cellular, biochemical, and molecular approaches, are being devised to inactivate selected ECM and cell surface proteins, or their genes, within intact embryos. Techniques that effectively probe the function of individual components of neuron-ECM interactions will help to unravel the complex events of nerve cell migration and growth cone navigation. However, the apparent multiplicity and potential redundancy of interactions between neurons and the ECM will continue to challenge our attempts to advance our understanding.

\section{References}

Acheson A, Sunshine JL, Rutishauser U (1991) NCAM polysialic acid can regulate both cell-cell and cell-substrate interactions. J Cell Biol 114:143-153.

Akeson R, Warren SL (1986) PC12 adhesion and neurite formation on selected substrates are inhibited by some glycosaminoglycans and a fibronectin-derived tetrapeptide. Exp Cell Res 162:347-362.

Andres JL, Stanley K, Cheifetz S, Massague J (1989) Membrane- 
anchored and soluble forms of betaglycan, a polymorphic proteoglycan that binds transforming growth factor- $\beta$. J Cell Biol 109:31373145 .

Andres JL, DeFalcis D, Noda M, Massague J (1992) Binding of two growth factor families to separate domains of the proteoglycan betaglycan. J Biol Chem 267:5927-5930.

Aquino DA, Margolis RU, Margolis RK (1984) Immunocytochemical localization of a chondroitin sulfate proteoglycan in nervous tissue. II. Studies in developing brain. J Cell Biol 99:1130-1139.

Auth D, Brawerman G (1992) A 33-kDa polypeptide with homology to the laminin receptor: component of translation machinery. Proc Natl Acad Sci USA 89:4368-4372.

Bartsch S, Bartsch U, Dorries U, Faissner A, Weller A, Ekblom P, Schachner M (1992) Expression of tenascin in the developing and adult cerebellar cortex. J Neurosci 12:736-749.

Bartsch U, Bartsch S, Dorries U, Schachner M (1992) Immunohistological localization of tenascin in the developing and lesioned adult mouse optic nerve. Eur J Neurosci 4:338-352.

Bate M (1976) Pioneer neurons in an insect embryo. Nature 260:5456.

Baumgartner S, Chiquet-Ehrismann R (1993) Ten, a Drosophila gene related to tenascin, shows selective transcript localization. Mech Dev 40:165-176.

Begovac PC, Shur BD (1990) Cell surface galactosyltransferase mediates the initiation of neurite outgrowth from PC12 cells on laminin. J Cell Biol 110:461-470.

Begovac PC, Hall DE, Shur BD (1991) Laminin fragment E8 mediates $\mathrm{PC} 12$ cell neurite outgrowth by binding to cell surface $\beta 1,4$ galactosyltransferase. J Cell Biol 113:637-644.

Bernfield M, Kokenyesi R, Kato M, Hinkes MT, Spring J, Gallo RL, Lose EJ (1992) Biology of the syndecans: a family of transmembrane heparan sulfate proteoglycans. Annu Rev Cell Biol 8:365-393.

Bidanset DJ, LeBaron R, Rosenberg L, Murphy-Ullrich JE, Hook M (1992) Regulation of cell substrate adhesion: effects of small galactosaminoglycan-containing proteoglycans. J Cell Biol 118:1523-1531.

Brauer PR, Yee JA (1993) Cranial neural crest cells synthesize and secrete a latent form of transforming growth factor $\beta$ that can be activated by neural crest cell proteolysis. Dev Biol 155:281-285.

Brittis PA, Canning DR, Silver J (1992) Chondroitin sulfate as a regular of neuronal patterning in the retina. Science 255:733-736.

Bronner-Fraser M (1986) An antibody to a receptor for fibronectin and laminin perturbs cranial neural crest development in vivo. Dev Biol 1 17:528-536.

Bronner-Fraser M (1987) Perturbation of cranial neural crest migration by the HNK-1 antibody. Dev Biol 123:321-331.

Bronner-Fraser M (1988) Distribution and function of tenascin during cranial neural crest development in the chick. J Neurosci Res 21: 135-147.

Bronner-Fraser M, Lallier T (1988) A monoclonal antibody against a laminin-heparan sulfate proteoglycan complex perturbs cranial neural crest migration in vivo. J Cell Biol 106:1321-1329.

Bronner-Fraser M, Artinger M, Muschler J, Horwitz AF (1992a) Developmentally regulated expression of $\alpha 6$ integrin in avian embryos. Development 115:197-211.

Bronner-Fraser M, Wolf JJ, Murray BA (1992b) Effects of antibodies against $\mathrm{N}$-cadherin and $\mathrm{N}$-CAM on the cranial neural crest and neural lube. Dev Biol 153:291-301.

Calof AL, Lander AD (1991) Relationship between neuronal migration and cell-substratum adhesion: laminin and merosin promote olfactory neuronal migration but are anti-adhesive. J Cell Biol 115: 779-794

Carbonetto S, Gruver MM, Turner DC (1983) Nerve fiber growth in culture on fibronectin, collagen and glycosaminoglycan substrates. J Neurosci 3:2324-2335.

Carey DJ, Evans DM, Stahl RC, Asundi VK, Conner KJ, Garbes P, Cizmeci-Smith $G$ (1992) Molecular cloning and characterization of $\mathrm{N}$-syndecan, a novel transmembrane heparan sulfate proteoglycan. J Cell Biol 117:191-201.

Castronovo V, Taraboletti G, Sobel ME (1991) Functional domains of the 67-kDa laminin receptor precursor. J Biol Chem 266:2044020446.

Chan BMC, Kassner PD, Schiro JA, Byers HR, Kupper TS, Hemler ME (1992) Distinct cellular functions mediated by different VLA integrin $\alpha$ subunit cytoplasmic domains. Cell 68:1051-1060.

Chang WS, Serikawa K, Allen K, Bentley D (1992) Disruption of pioneer growth cone guidance in vivo by removal of glycosylphosphatidylinositol-anchored cell surface proteins. Development 114: 507-519.

Chiquet-Ehrismann R (1990) What distinguishes tenascin from fibronectin? FASEB J 4:2598-2604.

Chiquet-Ehrismann R (1991) Anti-adhesive molecules of the extracellular matrix. Curr Opin Cell Biol 3:800-804.

Choung C-M, Crossin KL, Edelman GM (1987) Sequential expression and differential function of multiple adhesion molecules during the formation of cerebellar cortical layers. J Cell Biol 104:331-342.

Cole GJ, McCabe CF (1991) Identification of a developmentally regulated keratan sulfate proteoglycan that inhibits cell adhesion and neurite outgrowth. Neuron 7:1007-1018.

Cummings BJ, Su JH, Geddes JW, van Nostrand WE, Wagner SL, Cunningham DD, Cotman CW (1992) Aggregation of the amyloid precursor protein within degenerating neurons and dystrophic neurites in Alzheimer's disease. Neuroscience 48:763-777.

Damon DH, D'Amore PA, Wagner JA (1988) Sulfated glycosaminoglycans modify growth factor-induced neurite outgrowth in P12 cells. J Cell Physiol 135:293-300.

Damsky CH, Werb Z (1992) Signal transduction by integrin receptors for extracellular matrix: cooperative processing of extracellular information. Curr Opin Cell Biol 4:772-781.

Dana N, Fathallah DM, Arnaout MA (1991) Expression of a soluble and functional form of the human $\beta 2$ integrin CD11b/CD18. Proc Natl Acad Sci USA 88:3106-3110.

David G, Bai XB, van der Schueren B, Cassiman J-J, van den Berghe $\mathrm{H}$ (1992) Developmental changes in heparan sulfate expression: in situ detection with mAbs. J Cell Biol 119:961-975.

Davis GE, Manthorpe M, Engvall E, Varon S (1985) Isolation and characterization of rat Schwannoma neurite-promoting factor: evidence that the factor contains laminin. J Neurosci 5:2662-2671.

de Curtis I (1991) Neuronal interactions with the extracellular matrix. Curr Opin Cell Biol 3:824-831.

Delannet M, Duband J-L (1992) Transforming growth factor- $\beta$ control of cell-substratum adhesion during avian neural crest cell emigration in vitro. Development 116:275-287.

Dow KE, Riopelle RJ, Kisilevsky R (1991) Domains of neuronal heparan sulfate proteoglycans involved in neurite growth on laminin. Cell Tissue Res 265:345-351.

Drake SL, Klein DJ, Mickelson DJ, Oegema TR, Furcht LT, McCarthy JB (1992) Cell surface phosphatidylinositol-anchored heparan sulfate proteoglycan initiates mouse melanoma cell adhesion to a fibronectin derived heparin-binding synthetic peptide. J Cell Biol 117: $1331-1341$.

Duband J-L, Belkin AM, Syfrig J, Thiery JP, Koteliansky VE (1992) Expression of $\alpha 1$ integrin, a laminin-collagen receptor, during myogenesis and neurogenesis in the avian embryo. Development 116: $585-600$.

Durbec P, Gennarini G, Goridis C, Rougon G (1992) A soluble form of the F3 neuronal cell adhesion molecule promotes neurite outgrowth. J Cell Biol 117:877-887.

Engel J (1991) Common structural motifs in proteins of the extracellular matrix. Curr Opin Cell Biol 3:779-785.

Engvall E, Earwicker D, Day A, Muir D, Manthorpe M, Paulsson M (1992) Merosin promotes cell attachment and neurite outgrowth and is a component of the neurite-promoting factor of RN22 Schwannoma cells. Exp Cell Res 198:115-123.

Erickson HP (1993) Gene knockouts of c-src, transforming growth factor $\beta 1$, and tenascin suggest superfluous, nonfunctional expression of proteins. J Cell Biol 120:1079-1081.

Faassen AE, Schrager JA, Kelin DJ, Oegema TR, Couchman JR, McCarthy JB (1992) A cell surface chondroitin sulfate proteoglycan, immunologically related to $\mathrm{CD} 44$, is involved in type I collagenmediated melanoma cell motility and invasion. J Cell Biol 116:521531.

Faissner A, Kruse J (1990) J1/tenascin is a repulsive substrate for central nervous system neurons. Neuron 5:627-637.

Fessler JH, Fessler LI (1989) Drosophila extracellular matrix. In: Annual Review of Cell Biology (Palade GE, ed), pp 309-339. Palo Alto, CA: Annual Reviews.

Fichard A, Verna J-M, Olivares J, Saxod R (1991) Involvement of a chondroitin sulfate proteoglycan in the avoidance of chick epidermis by dorsal root ganglia fibers: a study using $\beta$-D-xyloside. Dev Biol 148:1-9. 
Fryer HJ, Kelly GM, Molinaro L, Hockfield S (1992) The high molecular weight Cat-301 chondroitin sulfate proteoglycan from brain is related to the large aggregating proteoglycan from cartilage, aggrecan. J Biol Chem 267:9874-9883.

Galileo DS, Majors J, Horwitz AF, Sanes JR (1992) Retrovirally introduced antisense integrin RNA inhibits neuroblast migration in vivo. Neuron 9:1117-1131.

Geisert EE Jr, Williams RC, Bidanset DJ (1992) A CNS proteoglycan associated with astrocytes in rat optic nerve. Brain Res 571:165-168

Ginsberg MH, Du X, Plow EF (1992) Inside-out integrin signaling. Curr Opin Cell Biol 4:766-771.

Golde TE, Estus S, Usiak M, Younkin LH, Younkin SG (1990) Expression of $\beta$ amyloid protein precursor mRNAs: recognition of a novel alternatively spliced form and quantitation in Alzheimer's disease using PCR. Neuron 4:253-267.

Goodman CS, Schatz C (1993) Developmental mechanisms that generate precise patterns of neuronal connectivity. Cell 10/Neuron 72 : $77-98$.

Goslin K, Banker G (1989) Experimental observations on the development of polarity by hippocampal neurons in culture. J Cell Biol 108:1507-1516.

Grosso LE, Park PW, Mecham RP (1991) Characterization of a putative clone for the 67-kilodalton elastin/laminin receptor suggests that it encodes a cytoplasmic protein rather than a cell surface receptor. Biochemistry 30:3346-3350.

Grumet M, Flaccus M, Margolis RU (1993) Functional characterization of chondroitin sulfate proteoglycans of brain: interactions with neurons and neural cell adhesion molecules. J Cell Biol 120:815-824.

Halfter W (1992) A heparan sulfate proteoglycan in developing axonal pathways. Soc Neurosci Abstr 18:578.

Hamelin M, Zhou Y, Ming-Wan S, Scott IM, Culotti JG (1993) Expression of the $u n c-5$ guidance receptor in the touch neurons of $C$ elegans steers their axons dorsally. Nature 364:327-330.

Hantaz-Ambroise D, Vigny M, Koenig J (1987) IIeparan sulfate proteoglycan and laminin mediate two different types of neurite outgrowth. J Neurosci 7:2293-2304.

Hathaway HJ, Shur BD (1992) Cell surface $\beta 1$,4-glactosyltransferase functions during neural crest cell migration and neurulation in vivo. J Cell Biol 117:369-382.

Haugen PK, McCarthy JB, Skubitz APN, Furcht LT, Letourneau PC (1990) Recognition of the A chain carboxy-terminal heparin binding region of fibronectin involves multiple sites: two contiguous sequences act independently to promote neural cell adhesion. J Cell Biol 111: 2733-2745.

Haugen PK, McCarthy JB, Roche KF, Furcht LT, Letourneau PC (1992a) Central and peripheral neurite outgrowth differs in preference for heparin-binding versus integrin-binding sequences. J Neurosci 12 ; 2034-2042.

Haugen PK, Letourneau PC, Drake SL, Furcht LT, McCarthy JB (1992b) A cell-surface heparan sulfate proteoglycan mediates neural cell adhesion in spreading on a defined sequence from the C-terminal cell and heparan binding domain of FN,FN-C/H II. J Neurosci 12:25972608

He HT, Finne J, Goridis C (1987) Biosynthesis, membrane association, and release of N-CAM-120, a phosphatidylinositol-linked form of the neural cell adhesion molecule. J Cell Biol 105:2489-2500.

Hedgecock EM, Culotti JG, Hall DH, Stern BD (1987) Genetics of cell and axon migrations in Caenorhabditis elegans. Development 100:365-382.

Hekmat A, Bitter-Suermann D, Schachner M (1990) Immunocytological localization of the highly polysialylated form of the neural cell adhesion molecule during development of the murine cerebellar cortex. J Comp Neurol 291:457-467.

Henchcliffe C, Garcia-Alonso L, Tang J, Goodman CS (1993) Genetic analysis of laminin A reveals diverse functions during morphogenesis in Drosophila. Development 118:325-337.

Hibbs ML, Xu H, Stacker SA, Springer TA (1991) Regulation of adhesion to ICAM-1 by the cytoplasmic domain of LFA-1 integrin beta subunit. Science 251:1611-1613

Hockfield S, Kalb RG, Zaremba S, Fryer H (1990) Expression of neural proteoglycans correlates with the acquisition of mature neuronal properties in the mammalian brain. Cold Spring Harb Symp Quant Biol $55 \cdot 505-514$

Hoffman S, Edelman GM (1987) A proteoglycan with HNK-1 anti- genic determinants is a neuron-associated ligand for cytotactin. Proc Natl Acad Sci USA 84:2523-2527.

Hoffman S, Crossin KL, Edelman GM (1988) Molecular forms, bindings functions and developmental expression patterns of cytotactin and CTB proteoglycan, an interactive pair of extracellular matrix molecules. J Cell Biol 106:519-532.

Hondermarck H, Deudon E, Boilly B (1992) Embryonic brain-derived heparan sulfate inhibits cellular membrane binding and biological activity of basic fibroblast growth factor. Dev Brain Res 68:247-253.

Hortsch M, Goodman CS (1991) Cell and substrate adhesion molecules in Drosophila. Annu Rev Cell Biol 7:505-557.

Hunter D, Shah V, Merlie J, Sanes J (1989a) A laminin-like adhesive protein concentrated in the synaptic cleft of the neuromuscular junction. Nature 338:229-234.

Hunter DD, Porter BE, Bulock JW, Adams SP, Merlie JP, Sanes JR (1989b) Primary sequence of a motor neuron-selective adhesive site in the synaptic basal lamina protein S-laminin. Cell 59:905-913.

Hunter DD, Cashman N, Morris-Valero R, Bulock JW, Adams SP, Sanes JR (1991) An LRE (leucine-arginine-glutamate)-dependent mechanism for adhesion of neurons to S-laminin. J Neurosci 11: 3960-3971.

Hunter DD, Llinas R, Ard M, Merlie JP, Sanes JR (1992a) Expression of S-laminin and laminin in the developing rat central nervous system. J Comp Neurol 323:238-251.

Hunter DD, Murphy MD, Olsson CV, Brunken WJ (1992b) S-laminin expression in adult and developing retina: a potential cue for photoreceptor morphogenesis. Neuron 8:399-413.

Husmann K, Faissner A, Schachner M (1992) Tenascin promotes cerebellar granule cell migration and neurite outgrowth by different domains in the fibronectin type III repeats. J Cell Biol 116:14751486.

Hynes RO (1992) Integrins: versatility, modulation, and signaling in cell adhesion. Cell 69:11-25.

Hynes RO, Lander AD (1992) Contact and adhesive specificities in the associations, migrations, and targeting of cells and axons. Cell 68 : 303-322.

Iida J, Skubitz APN, Furcht LT, Wayner EA, McCarthy JB (1992) Coordinate role for cell surface chondroitin sulfate proteoglycan and $\alpha 4-\beta 1$ integrin in mediating melanoma cell adhesion to fibronectin. J Cell Biol 118:431-444.

Iijima N, Oohira A, Mori T, Kitabatake K, Kohsaka S (1991) Core protein of chondroitin sulfate proteoglycan promotes neurite outgrowth from cultured neocortical neurons. J Neurochem 56:706-708.

Ishii N, Wadsworth WG, Stern BD, Culotti JG, Hedgecock EM (1992) Unc-6, a laminin-related protein, guides cell and pioneer axon migrations in C. elegans. Neuron 9:873-881.

Jackson RI, Busch SJ, Cardin AD (1991) Glycosaminoglycans: molecular properties, protein intcractions and rolc in physiological processes. Physiol Rev 71:481-539.

Jay DG, Keshishian H (1990) Laser inactivation of fasciclin I disrupts axon adhesion of grasshopper pioneer neurons. Nature 348:548-550.

Johnson-Green PC, Dow KE, Riopelle RJ (1991) Characterization of glycosaminoglycans produced by primary astrocytes in vitro. Glia $4: 314-321$.

Johnson-Green PC, Dow KE, Riopelle RJ (1992) Neurite growth modulation associated with astrocyte proteoglycans: influence of activators of inflammation. Glia 5:33-42.

Jones FS, Hoffman S, Cunningham BA, Edelman GM (1989) A detailed structural map of cytotactin: protein homologies, alternative RNA splicing and binding regions. Proc Natl Acad Sci USA 86:19051909.

Kalaria RN, Kroon SN, Grahovac I, Perry G (1992) Acetylcholinesterase and its association with heparan sulfate proteoglycans in cortical amyloid deposits of Alzheimer's disease. Neuroscience 51:177184.

Kallapur SG, Akeson RA (1992) The neural cell adhesion molecule (NCAM) heparin binding domain binds to cell surface heparan sulfate proteoglycans. J Neurosci Res 33:538-548.

Kaplony A, Zimmermann DR, Fischer RW, Imhof BA, Odermatt BF, Winterhalter KH, Vaughan L (1991) Tenascin $M_{r} 220,000$ isoform expression correlates with corneal cell migration. Development 105: $605-614$.

Katoh-Semba R, Oohira A, Kashiwamata S (1992) Nerve growth factor-induced changes in the structure of sulfated proteoglycans in PC12 pheochromocytoma cells. J Neurochem 59:282-289. 
Klar A, Baldassare M, Jessell TM (1992) F-spondin: a gene expressed at high levels in the floor plate encodes a secreted protein that promotes neural cell adhesion and neurite extension. Cell 69:95-110.

Kleinman HK, Weeks BS, Cannon FB, Sweeney TM, Sephel GC, Clement B, Zain M, Olson MOJ, Jucker M, Burrous BA (1991) Identification of a 110-kDa nonintegrin cell surface laminin-binding protein which recognizes an A chain neurite-promoting peptide. Arch Biochem Biophys 290:320-325.

Kuhn TB, Stoeckli ET, Condrau MA, Rathjen FG, Sonderegger P (1991) Neurite outgrowth on immobilized axonin-1 is mediated by a heterophilic interaction with L1(G4). J Cell Biol 115:1113-1126.

Kusche-Gullberg M, Garrison K, MacKrell AJ, Fessler LI, Fessler JH (1992) Laminin A chain: expression during Drosophila development and genomic sequence. EMBO I 11:4519-4527.

LaFont F, Rouget M, Triller A, Prochiantz A, Rousselet A (1992) In vitro control of neuronal polarity by glycosaminoglycans. Development 114:17-29.

Lallier T, Bronner-Fraser M (1992) $\alpha 1 \beta 1$ integrin on neural crest cells recognizes some laminin substrata in a $\mathrm{Ca}^{2+}$-independent manner. $\mathrm{J}$ Cell Biol 119:1335-1345.

Lallier T, Leblanc G, Artinger KB, Bronner-Fraser M (1992) Cranial and trunk neural crest cells use different mechanisms for attachment to extracellular matrices. Development 116:531-541.

Lance-Jones C, Landmesser L (1981) Pathway selection by chick lumbosacral motoneurons during normal development. Proc R Soc Lond [Biol] 214:1-18.

Landers RA, Hollyfield JG (1992) Proteoglycans in the mouse interphotoreceptor matrix. VI. Evidence for photoreceptor synthesis of chondroitin sulfate proteoglycan using genetically fractionated retinas. Exp Eye Res 55:345-356.

Landmesser L (1978) The development of motor projection patterns in the chick hind limb. J Physiol (Lond) 284:3391-3414.

Landmesser L, Dahm L, Tang J, Rutishauser U (1990) Polysialic acid as a regulator of intramuscular nerve branching during embryonic development. Neuron 4:655-667.

Laywell ED, Dorries U, Bartsch U, Faissner A, Schachner M, Steindler DA (1992) Enhanced expression of the developmentally regulated extracellular matrix molecule tenascin following adult brain injury. Proc Natl Acad Sci USA 89:2634-2638.

LeBlanc AC, Kovacs DM, Chen HY, Villare F, Tykocinski M, AutilioGambetti L, Gambetti P (1992) Role of amyloid precursor protein (APP): study with antisense transfection of human neuroblastoma. J Neurosci Res 31:635-645.

Lefcort F, Venstrom K, McDonald JA, Reichardt LF (1992) Regulation of expression of fibronectin and its receptor, $\alpha 5 \beta 1$, during development and regeneration of peripheral nerve. Development 116: 767-782.

Lein PJ, Higgins D, Turner DC, Flier LA, Terranova VP (1991) The $\mathrm{NCl}$ domain of type IV collagen promotes axonal growth in sympathetic neurons through interactions with the $\alpha 1 \beta 1$ integrin. J Cell Biol 113:417-428.

Lein PJ, Banker GA, Higgins D (1992) Laminin selectively enhances axonal growth and accelerates the development of polarity by hippocampal neurons in culture. Dev Brain Res 69:191-197.

Lemmon V, Burden SM, Payne HR, Elmselle GJ, Hlavin ML (1992) Neurite growth on different substrates: permissive versus instructive influences and the role of adhesive strength. J Neurosci 12:818-826.

Leppa S, Mali M, Miettinen HM, Jalkanen M (1992) Syndecan expression regulates cell morphology and growth of mouse mammary epithelial tumor cells. Proc Natl Acad Sci USA 89:932-936.

Leptin M, Bogaert T, Lehmann R, Wilcox M (1989) The function of PS integrins during Drosophila cmbryogencsis. Ccll 56:401-408.

Letourneau PC, Condic ML, Snow DM (1992) Extracellular matrix and neurite outgrowth. Curr Opin Gen Dev 2:625-634.

Leung-Hagensteijn C, Spence AM, Stern BD, Zhou Y, Su M-W, Hedgecock EM, Culotti JG (1992) UNC-5, a transmembrane protein with immunoglobulin and thrombospondin type 1 domains, guides cell and pioneer axon migrations in C. elegans. Cell 71:289-299.

Lewandowska K, Choi HU, Rosenberg LC, Zardi L, Culp LA (1987) Fibronectin-mediated adhesion of fibroblasts: inhibition by dermatan sulfate proteoglycan and evidence for a cryptic glycosaminoglycanbinding domain. J Cell Biol 105:1443-1454.

Liesi P, Seppala I, Trenkner E (1992) Neuronal migration in cerebellar microcultures is inhibited by antibodies against a neurite outgrowth domain in laminin. J Neurosci Res 33:170-176.
Lochter A, Vaughan L, Kaplony A, Prochiantz A, Schachner M, Faissner A (1991) J1/tenascin in substrate-bound and soluble form displays contrary effects on neurite outgrowth. J Cell Biol 113:1159-1171.

Luo L, Tully T, White K (1992) Human amyloid precursor protein ameliorates behavioral deficit of flies deleted for $A p p l$ gene. Neuron 9:595-605.

Margolis RK, Margolis RU (1989) Nervous tissue proteoglycans. Dev Neurosci 11:276-288.

McKeon RJ, Schreiber RC, Rudge JS, Silver J (1991) Reduction of neurite outgrowth in a model of glial scarring following CNS injury is correlated with the expression of inhibitory molecules on reactive astrocytes. J Neurosci 11:3398-3411.

Mecham RP (1991) Receptors for laminin on mammalian cells. FASEB J 5:2538-2546.

Mège RM, Nicolet $M$, Pinçon-Raymond $M$, Murawsky $M$, Rieger $F$ (1992) Cytotactin is involved in synaptogenesis during regeneration of the frog neuromuscular system. Dev Biol 149:381-394.

Merenmies J, Pihlaskari R, Laitinen J, Wartiovaara J, Rauvala H (1991) $30-\mathrm{kDa}$ heparin-binding protein of brain (amphoterin) involved in neurite outgrowth: amino acid sequence and localization in the filopodia of the advancing plasma membrane. J Biol Chem 266:1672216729.

Milward EA, Papadopoulos R, Fuller SJ, Moir RD, Small D, Beyreuther K, Masters CL (1992) The amyloid protein precursor of Alzheimer's disease is a mediator of the effects of nerve growth factor on neurite outgrowth. Neuron 9:129-137.

Minguell JJ, Hardy C, Tavassoli M (1992) Membrane-associated chondroitin sulfate proteoglycan and fibronectin mediate the binding of hemopoietic progenitor cells to stromal cells. Exp Cell Res 201: 200-207.

Mirre C, Le Parco Y, Knibiehler B (1992) Collagen IV is present in the developing CNS during Drosophila neurorogenesis. J Neurosci Res 31:146-155.

Muir D, Engvall E, Varon S, Manthorpe M (1989) Schwannoma cellderived inhibitor of the neurite promoting activity of laminin. J Cell Biol 109:2353-2362.

Muschler JL, Horwitz AF (1991) Down regulation of chicken $\alpha 5 \beta 1$ integrin fibronectin receptor during development. Development 113: 327-337.

Nakashima N, Miyazaki K, Ishikawa M, Yatohgo T, Ogawa H, Uchibori H, Matsumoto I, Seno N, Hayashi M (1992) Vitronectin diversity in evolution but uniformity in ligand binding and size of the core polypeptide. Biochim Biophys Acta 1120:1-10.

Neugebauer KM, Emmett CJ, Venstrom KA, Reichardt LF (1991) Vitronectin and thrombospondin promote retinal neurite outgrowth: developmental regulation and role of integrins. Neuron 6:345-358.

Nishiyama A, Dahlin K, Prince JT, Johnstone SR, Stallcup WB (1991) The primary structure of NG2, a novel membrane-spanning proteoglycan. J Cell Biol 114:359-371.

Noonan DM, Fulle A, Valente P, Cai S, Horigan E, Sasaki M, Yamada Y, Hassell JR (1991) The complete sequence of perlecan, a basement membrane heparan sulfate proteoglycan, reveals extensive similarity with laminin A chain, low density lipoprotein-receptor, and the neural cell adhesion molecule. J Biol Chem 266:22939-22947.

Norbeck BA, Feng Y, Denburg JL (1992) Molecular gradients along the proximal-distal axis of embryonic insect legs: possible guidance cues of pioneer axon growth. Development 116:467-479.

Norenberg U, Wille H, Wolff M, Frank R, Rathjen RG (1992) The chicken neural extracellular matrix molecule restrictin: similarity with EGF-, fibronectin type III-, and fibrinogen-like motifs. Neuron 8:849863.

Oakley RA, Tosney KW (1991) Peanut agglutinin and chondroitin6-sulfate are molecular markers for tissues that act as barriers to axon advance in the avian embryo. Dev Biol 147:187-206.

Oohira A, Matsui F, Katoh-Semba R (1991) Inhibitory effects of brain chondroitin sulfate proteoglycans on neurite outgrowth from PC12D cells. J Neurosci 11:822-827.

O'Shea KS, Liu L-HJ, Dixit VM (1991) Thrombospondin and a 140 $\mathrm{kD}$ fragment promote adhesion and neurite outgrowth from embryonic central and peripheral neurons and from PC12 cells. Neuron 7:231-237.

Osterhout DJ, Frazier WA, Higgins D (1992) Thrombospondin promotes process outgrowth in neurons from the peripheral and central nervous systems. Dev Biol 150:256-265.

Pagani F, Zagato L, Vergani C, Giorgio C, Sidoli A, Baralle FE (1991) 
Tissue-specific splicing pattern of fibronectin messenger RNA precursor during development and aging in rat. J Cell Biol 113:12231229.

Parkkinen J, Rauvala H (1991) Interactions of plasminogen and tissue plasminogen activator (t-PA) with amphoterin: enhancement of t-PA catalyzed plasminogen activation by amphoterin. J Biol Chem 266: 16730-16735.

Perez RG, Halfter W (1993) Tenascin in the developing chick visual system: distribution and potential role as a modulator of retinal axon growth. Dev Biol 156:278-292.

Perris R, Johansson S (1990) Inhibition of neural crest cell migration by aggregating chondroitin sulfate proteoglycans is mediated by their hyaluronan-binding region. Dev Biol 137:1-12.

Perris R, Krotoski D, Lallier T, Domingo C, Sorrell JM, Bronner-Fraser $M$ (1991) Spatial and temporal changes in the distribution of proteoglycans during avian neural crest development. Development 111: 583-599.

Pesheva P, Spiess E, Schachner M (1989) J1-160 and J1-180 are oligodendrocyte-secreted nonpermissive substrates for cell adhesion. J Cell Biol 109:1765-1778.

Pesheva P, Gennarini G, Goridis C, Schachner M (1993) The F3/11 cell adhesion molecule mediates the repulsion of neurons by the extracellular matrix glycoprotein J1-160/180. Neuron 10:69-82.

Pindzola RR, Doller C, Silver J (1993) Putative inhibitory extracellular matrix molecules at the dorsal root entry zone of the spinal cord during development and after root and siatic nerve lesions. Dev Biol 156:34-48.

Pomeranz HD, Sherman DL, Smallheiser NR, Tennyson VM, Gershon MD (1991) Expression of a neurally related laminin binding protein by neural crest-derived cells that colonize the gut: relationship to the formation of enteric ganglia. J Comp Neurol 313:625-642.

Prieto AL, Andersson-Fisone C, Crossin KL (1992) Characterization of multiple adhesive and counteradhesive domains in the extracellular matrix protein cytotactin. J Cell Biol 119:663-678.

Rapraeger A, Jalkanen M, Bernfield M (1986) Cell surface proteoglycan associates with the cytoskeleton at the basolateral cell surface of mousc mammary epithelial cells. J Cell Biol 103:2683-2696.

Ratner N, Hong D, Lieberman MA, Bunge RP, Glaser L (1988) The neuronal cell-surface molecule mitogenic for Schwann cells is a heparin-binding protein. Proc Natl Acad Sci USA 85:6992 6996.

Rauch U, Gao P, Janetzko A, Flaccus A, Hilgenberg L, Tekotte M, Margolis RK, Margolis RU (1991) Isolation and characterization of developmentally regulated chondroitin sulfate and chondroitin/ keratan sulfate proteoglycans of brain identified with monoclonal antibodies. J Biol Chem 266:14785-14801.

Rauch U, Karthikeyan L, Maurel P, Margolis RU, Margolis RK (1992) Cloning and primary structure of neurocan, a developmentally regulated, aggregating chondroitin sulfate protenglycan of brain. I Biol Chem 267:19536-19547.

Reichardt LF, Tomaselli TJ (1991) Extracellular matrix molecules and their receptors. Annu Rev Neurosci 14:531-570.

Reist NE, Magill C, McMahan UJ (1987) Agrin-like molecules at synaptic sites in normal, denervated and damaged skeletal muscles. J Cell Biol 105:2457-2469.

Riopelle RJ, Dow KE (1991) Neurite formation on laminin: effects of a galactosyltransferase on primary sensory neurons. Brain Res 541: 265-272.

Runyan RB, Maxwell GD, Shur BD (1986) Evidence for a novel enzymatic mechanism of neural crest cell migration on extracellular glycoconjugate matrices. J Cell Biol 102:432-441.

Ruoslahti E (1989) Proteoglycans in cell regulation. J Biol Chem 264: 13369-13372.

Rutishauser U (1989) Polysialic acid as a regulator of cell interactions. In: Neurobiology of glycoconjugates (Margolis RU, Margolis RK, ed), pp 367-382. New York: Plenum.

Saga Y, Yagi T, Ikawa Y, Sakakura T, Aizawa S (1992) Mice develop normally without tenascin. Genes Devel 6:1821-1831.

Salmivirta M, Rauvala H, Elenius K, Jalkanen M (1992) Neurite growth-promoting protein (amphoterin, p30) binds syndecan. Exp Cell Res 200:444-451.

Saunders S, Bernfield M (1988) Cell surface proteoglycan binds mouse mammary epithelial cells to fibronectin and behaves as a receptor for interstitial matrix. J Cell Biol 106:423-430.

Schnipper JL, Shankland MS, Jay DG (1992) Single cell laser inac- tivation of fasciclin 11 perturbs axonogenesis in the grasshopper limb bud. Soc Neurosci Abstr 18:1461.

Schubert D, Schroeder R, LaCorbiere M, Saitoh T, Cole G (1988) Amyloid $\beta$ protein is possibly a heparan sulfate proteoglycan core protein. Science 241:223-226.

Schwartz NR, Smalheiser NR (1989) Biosynthesis of glycosaminoglycans and proteoglycans. In: Neurobiology of glycoconjugates (Margolis RU, Margolis RK, eds), pp 151-186. New York: Plenum.

Schweighoffer T, Shaw S (1992) Adhesion cascades: diversity through combinatorial strategies. Curr Opin Cell Biol 4:824-829.

Shatz CJ, Ghosh A, McConnell SK, Alendoerfer KL, Friauf E, Antonini A (1990) Pioneer neurons and target selection in cerebral cortical development. Cold Spring Harbor Symp Quant Biol 55:469-480.

Sheppard AM, Hamilton SK, Pearlman AL (1991) Changes in the distribution of extracellular matrix components accompany early morphogenetic events of mammalian cortical development. J Neurosci 11:3928-3942.

Shiga T, Oppenheim RW (1991) Immunolocalization studies of putative guidance molecules used by axons and growth cones of intersegmental interneurons in the chick embryo spinal cord. J Comp Neurol 310:234-252.

Shioi J, Anderson JP, Ripelinno JA, Robakis NK (1992) Chondroitin sulfate proteoglycan form of the Alzheimer's $\beta$-amyloid precursor. J Biol Chem 267:13819-13822

Shioi J, Refolo LM, Efthimiopoulos S, Robakis NK (1993) Chondroitin sulfate proteoglycan form of cellular and ccll-surfacc Alzhcimer amyloid precursor. Neurosci Lett 154:121-124.

Skubitz APN, Letourneau PC, Wayner E, Furcht LT (1991) Synthetic peptides from the carboxy-terminal globular domain of the A chain of laminin: their ability to promote cell adhesion and neurite outgrowth, and interact with heparin and the $\beta 1$ integrin subunit. J Cell Biol 115:1137-1148.

Smalheiser NR, Collins BJ (1992a) Characterization of a novel set of membrane antigens associated with axonal growth. I. Biochemical and functional studies. Dev Brain Res 69:215-223.

Smalheiser NR, Collins BJ (1992b) Characterization of a novel set of membrane antigens associated with axonal growth. II. Expression in the chick central nervous system. Dev Brain Res 69:225-231.

Smalheiser NR, Collins BJ, Sharma SC (1992) Characterization of a novel set of membrane antigens associatcd with axonal growth. III. Expression in the regenerating goldfish optic nerve and tectum. Dev Brain Res 69:277-282.

Snow AD, Mar H, Nochlin D, Kresse H, Wight TN (1992) Peripheral distribution of dermatan sulfate proteoglycans (decorin) in amyloidcontaining plaques and their presence in neurofibrillary tangles of Alzheimer's disease. J Histochem Cytochem 40:105-113.

Snow DM, Letourneau PC (1992) Neurite outgrowth on a step gradient of chondroitin sulfate proteoglycan (CS-PG). J Neurobiol 23:322336.

Snow DM, Lemmon V, Carrino DA, Caplan AI, Silver J (1990a) Sulfated proteoglycans in astroglial barriers inhibit neurite outgrowth in vitro. Exp Neurol 109:111-130.

Snow DM, Steindler DA, Silver J (1990b) Molecular and cellular characterization of the glial roof plate of the spinal cord and optic tectum: a possible role for a proteoglycan in the development of an axon barrier. Dev Biol 138:359-376.

Snow DM, Watanabe M, Letourneau PC, Silver J (1991) A chondroitin sulfate proteoglycan may influence the direction of retinal ganglion cell outgrowth. Development 113:1473-1485.

Snow DM, Atkinson P, Hassinger T, Kater SB, Letourneau PC (1993) Growth cone intracellular calcium levels are elevated upon contact with sulfated proteoglycans. Soc Neurosci Abstr 19:in press.

Solowska J, Edelman JM, Albelda SM, Buck CA (1991) Cytoplasmic and transmembrane domains of integrin $\beta 1$ and $\beta 3$ subunits are functionally interchangeable. J Cell Biol 114:1079-1088.

Sonderegger P, Rathjen FG (1992) Regulation of axonal growth in the vertebrate nervous system by interactions between glycoproteins belonging to two subgroups of the immunoglobulin supcrfamily. J Cell Biol 119:1387-1394.

Spring J, Beck K, Chiquet-Ehrismann R (1989) Two contrary functions of tenascin: dissection of active sites by recombinant tenascin fragments. Cell 59:325-334.

Stoeckli ET, Kuhn TB, Duc C, Ruegg MA, Sonderegger P (1991) The axonally secreted protein axonin-1 is a potent substratum for neurite growth. J Cell Biol 112:449-455. 
Strittmater SM, Fishman MC (1991) The neuronal growth cone as a specialized transduction system. Bioessays 13:127-134.

Su JH, Cummings BJ, Cotman CW (1992) Localization of heparan sulfate glycosaminoglycan and proteoglycan core protein in aged brain and Alzheimer's disease. Neuroscience 51:801-813.

Sumi Y, Dent MAR, Owen DE, Seeley PJ, Morris RJ (1992) The expression of tissue and urokinase-type plasminogen activators in neural development suggests different modes of proteolytic involvement in ncuronal growth. Development 116:625-637.

Sutherland AE, Sanderson RD, Mayes M, Seibert M, Calarco PG, Bernfield M, Damsky CH (1991) Expression of syndecan, a putative low affinity fibroblast growth factor receptor, in the early mouse embryo. Development 113:339-351.

Suzuki T, Nairn AC, Gandy SE, Greengard P (1992) Phosphorylation of Alzheimer amyloid precursor protein by protein kinase $\mathrm{C}$. Neuroscience 48:755-761.

Tang J, Landmesser L, Rutishouser U (1992) Polysialic acid influences specific pathfinding by avian motoneurons. Neuron 8:1031-1044.

Tashiro K-I, Sephel GC, Greatorex D, Sasaki M, Shirashi N, Martin GR, Kleinman HK, Yamada Y (1991) The RGD containing site of the mouse laminin A chain is active for cell attachment, spreading, migration and neurite outgrowth. J Cell Physiol 146:451-459.

Thiery JP, Boyer B (1992) The junction between cytokines and cell adhesion. Curr Opin Cell Biol 4:782-792.

Threlkeld A, Adler R, Hewitt AT (1989) Proteoglycan biosynthesis by chick embryo retina glial-like cells. Dev Biol 132:559-568.

Tian S-S, Tsoulfas P, Zinn K (1991) Three receptor-linked proteintyrosine phosphatases are selectively expressed on central nervous system axons in the Drosophila embryo. Cell 67:675-685.

Tosney K, Landmesser L (1985) Development of the major pathways for neurite outgrowth in the chick hindlimb. Dev Biol 109:193-214

Trautman MS, Kimelman J, Bernfield M (1991) Developmental expression of syndecan, an integral membrane proteoglycan, correlates with cell differentiation. Development 111:213-220.

Turnbull JE, Fernig DG, Ke Y, Wilkinson MC, Gallagher JT (1992) Identification of the basic fibroblast growth factor binding sequence in fibroblast heparan sulfate. J Biol Chem 267:10337-10341.

Verna J-M, Fichard A, Saxod R (1989) Influence of glycosaminoglycans on neurite morphology and outgrowth patterns in vitro. Int $\mathbf{J}$ Dev Neurosci 7:389-399.

Walicke P (1988) Interactions between basic fibroblast growth factor (FGF) and glycosaminoglycans in promoting neurite outgrowth. Exp Neurol 102:144-148.

Walicke PA (1989) Novel neurotrophic factors, receptors, and oncogenes. Annu Rev Neurosci 12:103-126.
Wang L, Denburg JL (1992) A role for proteoglycans in the guidance of a subset of pioneer axons in cultured embryos of the cockroach. Neuron 8:701-714.

Wehrle B, Chiquet M (1990) Tenascin is accumulated along developing peripheral nerves and allows neurite outgrowth in vitro. Development 110:410-415.

Wehrle-Haller B, Koch M, Baumgartner S, Spring J, Chiquet M (1992) Nerve-dependent and -independent tenascin expression in the developing chick limb bud. Development 112:627-637.

Wright TC, Castellot JJ, Karnovsky MJ (1989) Regulation of cellular proliferation by heparin and heparan sulfate. In: Heparin (Lane DA, Lindahl U, eds), pp 295-316. London: Arnold.

Wu D-Y, Silver J, Schneider JE, Jhaveri S (1991) The barrier function of tectal midline glial cells and its association with proteoglycan distribution. Soc Neurosci Abstr 17:741.

Yamada Y, Kleinman HK (1992) Functional domains of cell adhesion molecules. Curr Opin Cell Biol 4:819-823.

Yang G, Douville P, Gee S, Carbonetto S (1992) Nonintegrin laminin receptors in the nervous system: evidence for lack of a relationship to P40. I Neurobiol 23:491-506.

Yang P, Yin X, Rutishauser U (1992) Intercellular space is affected by the polysialic acid content of NCAM. J Cell Biol 116:1487-1496.

Yang X, Seow KT, Bahri SM, Oon SH, Chia W (1991) Two Drosophila receptor-like tyrosine phosphatase genes are expressed in a subset of developing axons and pioneer neurons in the embryonic CNS. Cell 67:661-673.

Yayon A, Klagsbrun M, Esko JD, Leder P, Ornitz DM (1991) Cell surface, heparin-like molecules are required for binding of basic fibroblast growth factor to its high affinity receptor. Cell 64:841-848.

Yip JW, Yip YPL (1992) Laminin-developmental expression and role in axonal outgrowth in the peripheral nervous system of the chick. Dev Brain Res 68:23-33.

Zisch AH, D'Alessandri L, Ranscht B, Falchetto R, Winterhalter $\mathrm{KH}$, Vaughan L (1992) Neuronal cell adhesion molecule contactin/F1 1 binds to tenascin via its immunoglobulin-like domains. J Cell Biol 119:203-213.

Zusman S, Patel-King RS, Ffrench-Constant C, Hynes RO (1990) Requirements for integrins during Drosophila development. Development 108:391-402.

Zusman S, Grinblat Y, Ycc G, Kafatos FC, Hynes RO (1993) Analyses of PS integrin functions during Drosophila development. Development 118:735-750. 